\title{
Astronomy in additional education in Kazakhstan
}

\author{
Vera Zagainova \\ Republican Centre of Academic Methods in Additional Education, \\ Mitina 6, 050020 Almaty, Republic of Kazakhstan \\ email: zagainova.vera@gmail.com
}

\begin{abstract}
The merging of astronomy and physics into one subject in Kazakhstan's schools has hampered the knowledge of astronomy that had been established over tha past years. It is necessary to create a new system of aspace education for schoolchildren and the system of additional education should be leading this work. Additional education of astronomy in Kazakhstan began with astronomical clubs in the 1960s. In this paper a new system of additional education of astronomy in Kazakhstan is proposed..
\end{abstract}

Keywords. Education, schoolchildren, space

\section{Introduction}

It is important to start working with kids interested in the cosmos at an early school age, using different forms and methods of education. Regrettably, in the 21st century, the century when we most probably will tremendously broaden our mastery of outer space, fly to other planets, and possibly even to other stars, astronomy in Kazakhstan is integrated in physics and the number of hours for it has been reduced (Table 1).

The integration of astronomy and physics into one subject destroyed the teaching of astronomical concepts, well established in school over the past years. It is therefore necessary to create a new system for astronomy/space education for schoolchildren. Additional education should be leading this work.

\section{Additional educaton in astronomy}

Additional education of children is an essential part of the system of continuous education, required to provide a child with additional means for spiritual, moral, intellectual, aesthetic and physical development, as well as to fulfil their creative and educational needs. Additional education has an opportunity to increase and deepen children's knowledge and skills, received in school, as well as to highlight guidelines to his future profession.

In different countries a term "additional education" can be replaced by the term "nonformal education", "outside of school education", "free time programs", etc. According to the UNESCO classifications, non-formal education includes academic programs and courses, organised and conducted outside of the traditional education system, where results of this education are not necessary confirmed with respective certificate.

Among C.I.S. countries Russia has the highest incidence of additional education (up to $70 \%$ in some regions, $40 \%$ on average). The inclusion of school children in additional education in Kazakhstan is similar to the one in Baltic countries (slightly more than 20\%). The additional education system in Kazakhstan in its present renewed form was 
Table 1. Astronomical topics in Physics courses

\begin{tabular}{|c|c|c|}
\hline Level & Hours & $\begin{array}{l}\text { Astronomical topics in physics courses (primary and secondary } \\
\text { school) }\end{array}$ \\
\hline 7 th grade & $7 \mathrm{~h}$ & $\begin{array}{l}\text { The science of Astronomy. Relationships with other science. Movements of } \\
\text { planets and annual motion of the Sun. Ancient vision about Solar system. } \\
\text { Copernicus' heliocentric system. }\end{array}$ \\
\hline 8 th grade & $5 \mathrm{~h}$ & $\begin{array}{l}\text { Thermodynamic conditions (Moon, Mars, Venus). Magnetic fields (Earth and } \\
\text { other celestial bodies). The Sun. Solar/Moon eclipses. The telescope. }\end{array}$ \\
\hline 9th grade & $6 \mathrm{~h}$ & $\begin{array}{l}\text { Celestial sphere and celestial coordinates. The energy of the Sun and stars. } \\
\text { Physics and astronomy and their role to understanding of the nature. }\end{array}$ \\
\hline $10 \mathrm{t}$ & $0 \mathrm{~h}$ & There is no astronomy !!!! \\
\hline $\begin{array}{l}\text { 11th (general orienta- } \\
\text { tion) }\end{array}$ & $7 \mathrm{~h}$ & $\begin{array}{l}\text { Stellar motions. The Universe and its structure and evolution. Composition, } \\
\text { evolution and the main features of the Sun and other stars. The Galaxies, } \\
\text { Nebulae. Black and white holes. }\end{array}$ \\
\hline $\begin{array}{l}\text { 11th (physico- } \\
\text { mathematical ori- } \\
\text { entation) }\end{array}$ & $12 \mathrm{~h}$ & $\begin{array}{l}\text { Night sky and basic orientation among stars. World of the stars. Distances } \\
\text { to stars. Variable stars. The Sun - a day star. Sun's structure and main fea- } \\
\text { tures. Sun-Earth relationship. Planetary systems of stars. The Solar system. } \\
\text { Terrestrial planets. Gas giants. Minor planets of the Solar system. The limits } \\
\text { of the Solar system. Our Galaxy. Discovery of other galaxies. Quasars. The } \\
\text { Universe. }\end{array}$ \\
\hline
\end{tabular}

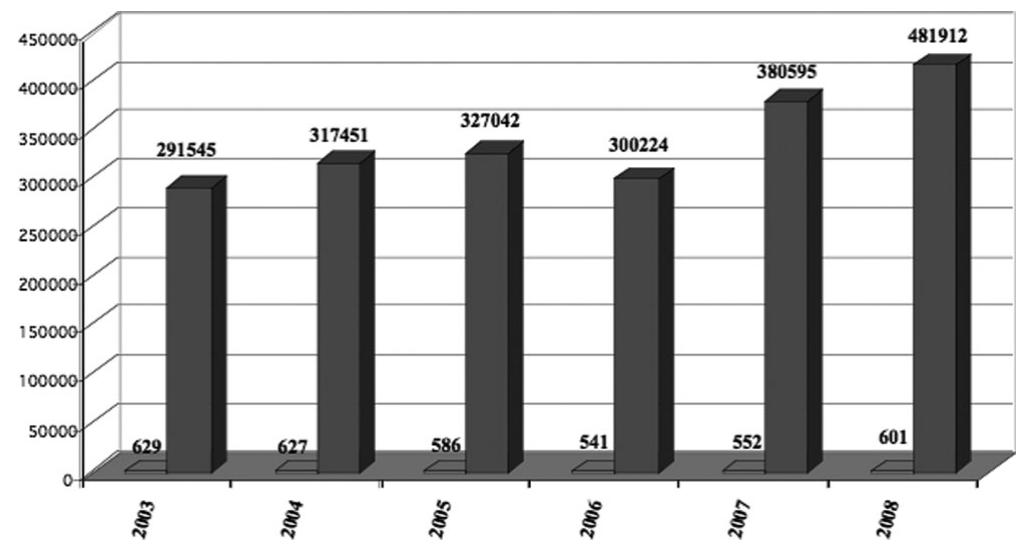

Figure 1. Total number of organisations of additional education (blue) and number of students in them (violet).

developed just in the past few years. Additional education is in great demand in Kazakhstan because of its synergy of tutoring, training and child's personality development and requires constant attention and support from society and the state.

In the early 1990s the network of additional education organisations of Kazakhstan (consisted of 1727 organizations) was reorganised. By the year 2000 only a third of them survived. As of 2000 a gradual recovery of children's additional education system has begun (Fig. 1).

The main lines of supplementary educational programs are following:

- Science and engineering (including astronomy);

- Sports;

- Artistic and aesthetic activities;

- Hiking and local lore;

- Ecology and biology;

- Military-patriotic;

- Social and pedagogical sciences and other.

They are carried out in houses, palaces, centres, stations, etc. The Ministry of Education of Kazakhstan accepted a decision to prepare to convert state schools into profile 
education centres. Full and realistic understanding of modern professions is an important component of modern school education as any other discipline. The orientation of schoolchildren towards professions was always one of the primary tasks of additional education as well. Among modern age profession there are ones linked to the creation, usage and development of space technology. For Kazakhstan these are especially of current importance.

Today more than 130 countries have their own national space programmes and develop own space technologies. Such programmes are also established in our country as well. Kazakhstan is in fact the cradle of space flights. The space-vehicle launching site Baikonur is a pride of our country.

The founder of the Astrophysical institute of Kazakhstan, Dr. Fesenko, in his article "Astronomical education and progress" (see "Earth and Universe" magazine 1985) wrote:

"Knowledge of astronomy always had a strong influence on ones' world outlook ... In the last decades a rôle of the astronomical knowledge increased tremendously. Astronomy became one of the scientific bases for space development. Development of the space technology, microelectronics and rapid accumulation of knowledge about Universe, strengthens the confidence in the power of the mind and its ability to master the Solar System. Each well-educated person needs astronomy. It explains things we see every day and should understand well... There is no doubt that development of astronomical education will promote progress of a society."

We need well-educated personnel to work in the field of space technologies. Space education comprises the fundamental knowledge of astronomy, outer space and rocketspace technology. The main objects of schoolchildren's space education are:

(a) Study and practical application of knowledge about the cosmos and space technology;

(b) Upbringing ecological consciousness and responsibility not only on a country or at the Earth's level but also the cosmos/universe as a whole;

(c) Forming scientific space outlook;

(d) Utilisation of knowledge about Cosmos for spiritual and moral education of school children.

\section{Impact of astronomy clubs}

The rôle of the additional education in space education for schoolchildren becomes even more important. Our Republic accumulated a lot of experience in outside of school astronomy studies. Additional education of Astronomy in Kazakhstan began with astronomical clubs, which leaded its history to the 1960s. For more than thirty years astronomy clubs actively worked in various cities of Kazakhstan: Almaty, Rudny, Aktobe, Taldykorgan, Leninsk, Satpaev, Chimkent, Pavlodar, Kzyl-Orda, Petropavlovsk, Atyrau.

In many clubs and centres children achieved substantial success: students built a Planetarium, a 216-mm reflector and a Foucault pendulum in a village of Tokushi (Petropavlovsk region); at the Schoolchildren Palace of Rudny city, kids built several astronomical instruments and conducted regular observations of variable stars and comets, and during a solar eclipse they obtained beautiful pictures of the solar corona. The Regional Planetarium of Aktobe organises more than 550 events annually. During the past 40 years this Planetarium received over a million visitors.

Baikonur also deserves a special mention. Using the International Space School of Baikonur as a base, kids not only study regular subjects, but also engage in subdivisions and on a space-rocket complex "Energy simulator". Many times these kids won prises at International Olympiads and tournaments, participated in International Space Schools 


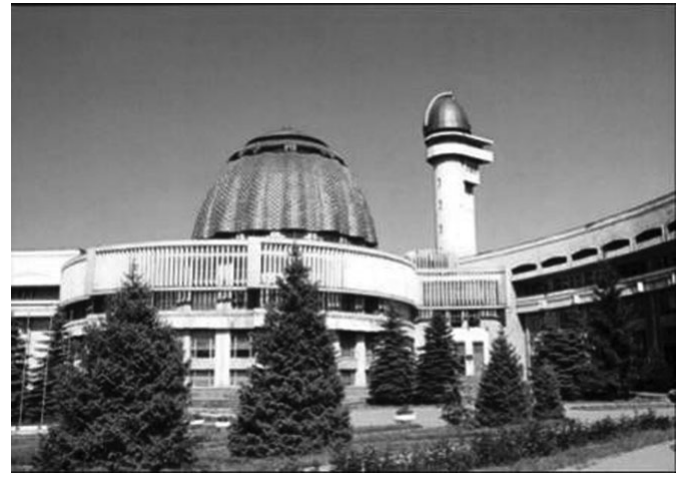

Figure 2. The Republican Palace of Schoolchildren.

and conferences of students. On behalf of International Space School of Baikonur, the Republican centre of academic methods in supplementary education (RCAMSE) received an offer to work together and undertake national and international events in the area of space education, using their base.

A pride among young astronomers of Kazakhstan has always been the Observatory of the Republican Palace of Schoolchildren, built in 1983 (Fig. 2). A unique equipment (German Planetarium Zeiss ZKP-2, Japanese telescope with a $25 \mathrm{~cm}$ mirror, literature on methods, software, video and films) successfully helps the teaching needs and allows one developing a cursus on astronomy among students. The Observatory for children became the persisting experimental platform of using both old practised forms of popular astronomy and new untried methods. Seminars for teachers of astronomy, lectures and practical observations for high school students, lectures in Planetarium, extra-mural astronomical Olympiads, these are just some examples of activities in this Observatory to help schools in the study of astronomy.

\section{New streams for additional education in astronomy}

All this work can be presented as a system of additional education of astronomy in Kazakhstan (Table 2). The nine main streams of this system passed approbation in Observatory of Republican Palace of Schoolchildren for a period of more than ten years and have proved to be viable. Let's take a look at some of them. Since 1986 at the Observatory of Republican Palace of Schoolchildren (RPS) we run an experiment. For four hours, which were allocated in school to observations (annually), each of more than one hundred schools in Almaty are invited to the Observatory (on a well-defined schedule). Two hours are dedicated to observations of the night sky in the Fall-Winter period and two hours are spent observingthe Sun in the Spring. The offer of the Observatory of RPS sparked interest among schools. Later on the Observatory organised a study group, which was called "Practical astronomy", and was dedicated to work with schools.

Some schools found that four hours of observations were not enough. It is not enough. They wanted to have at least a few lectures to be given by professionals using the Japanese telescope and the German planetarium of the Observatory RPS as well.

In October of 1976 a Petite Academy of Sciences of Schoolchildren of Kazakhstan (PASS) was created. It had more than 10 departments and the Department of Astronomy always was in the lead. The Petite Academy of Sciences of Schoolchildren of Kazakhstan became a leading form of academic and research activities for students. Astronomy is one of the very few sciences which has problems approachable by schoolchildren, their 
Table 2. Nine streams in additional education in astronomy

\begin{tabular}{|c|c|}
\hline $\begin{array}{l}\text { 1. Training and development pro- } \\
\text { grams }\end{array}$ & Astronomy clubs for children of younger age Young astronomer \\
\hline 2. Enriched programs & $\begin{array}{l}\text { Astronomy clubs for children of middle age Astrophysics, Astro- } \\
\text { program }\end{array}$ \\
\hline 3. Craft programs & $\begin{array}{l}\text { Initial professional training with a certificate issued upon comple- } \\
\text { tion in clubs Telescope construction, Astronomer, Observer }\end{array}$ \\
\hline 4. Advanced programs & $\begin{array}{l}\text { 1. Scientific associations of students } 2 \text {. Petite Academy of Sciences } \\
\text { of Schoolchildren Department of Astronomy }\end{array}$ \\
\hline $\begin{array}{l}\text { 5. Narrowed programs aimed } \\
\text { at astronomy popularisation } \\
\text { amongst schoolchildren }\end{array}$ & $\begin{array}{l}\text { 1. Study group Practical astronomy at Observatory. 2. Program } \\
\text { Space patrol and others }\end{array}$ \\
\hline 6. Remote programs & 1. Extra-mural courses and Olympiads; 2.Internet; 3 . TV and video \\
\hline $\begin{array}{l}\text { 7. Work with teachers of astron- } \\
\text { omy }\end{array}$ & $\begin{array}{l}\text { 1. Seminars for teachers of astronomy; } 2 \text {. Curriculum for teaches } \\
\text { to increase qualification; } 3 \text {. Consultations }\end{array}$ \\
\hline $\begin{array}{l}\text { 8. Bank of programs (secondary } \\
\text { and additional education) }\end{array}$ & $\begin{array}{l}\text { 1. Educational programs; } 2 \text {. Copyrighted educational programs; } 3 . \\
\text { Narrow-topic programs }\end{array}$ \\
\hline 9. Methodical literature & $\begin{array}{l}\text { 1. Methodical recommendations; } 2 \text {. Astronomy textbooks; } 3 \text {. Pop- } \\
\text { ular scientific literature; } 4 \text {. Didactical material }\end{array}$ \\
\hline
\end{tabular}

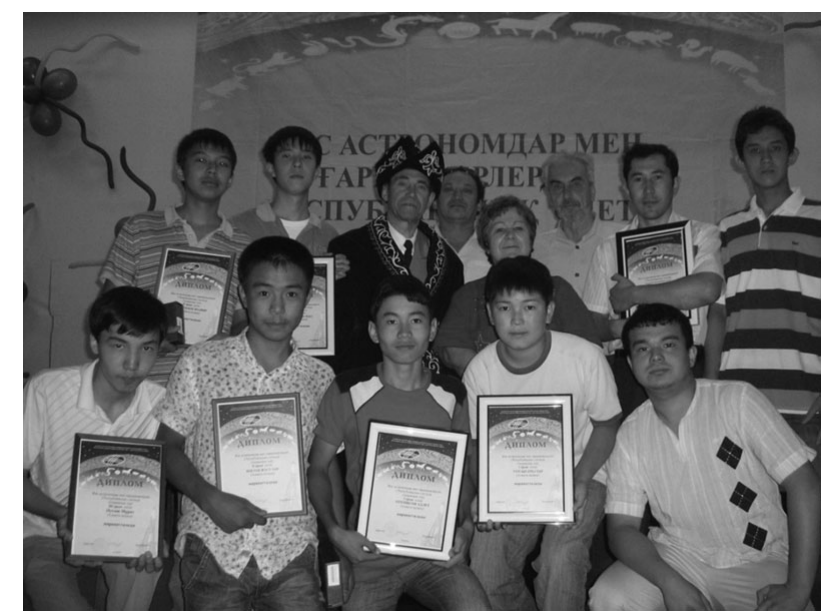

Figure 3. Participants and winners of the Republican Rally.

contribution to such problems can still be significant. During some 5-6 years students progressed from performing simplest exploratory tasks to a level where they set targets, develop approaches and perform research all by themselves. About $98 \%$ of members of PASS continue their education after high school choosing the same major, more than half of them continue scientific work upon completion of post secondary education.

In the 1990s and 2000s, students from Kazakhstan continued to participate successfully in International events: State level summer school -a session hold in Ufa in 1990, rally of young astronomers, of what now become C.I.S. in 1992; in 2000 an International contest Intellectuals of the 21st century in Bishkek, the 10th International rally of young astronomers in 2001 in Samara.

To sum up everything mentioned above, we can say that during 1970-90s up to $10 \%$ of high school students (which is about $0.5 \%$ of all school children) studied astronomy through the means of additional formation.

Unfortunately the reorganisation of the network of additional education organisations in the 1990s impacted astronomy as well. Many organisations no longer exist. Many forms of work changed. In 2004 the Republican Palace of Schoolchildren was reformed to become the "Republican centre of academic methods in additional education" (RCAMAE) and 
teaching methods for astronomy changed. For instance, the special training program for the International astronomy Olympiads was introduced.

To restore common system of space education for schoolchildren, in June of 2008, our centre for the first time organised the Republican Rally of young astronomers and astronauts, where participants of future International Astronomy Olympiads were officially selected. Some 90 schoolchildren participated in the rally, representing all major regions of Kazakhstan (Fig. 3). The results of the rally have shown that strong centres on space education for schoolchildren survived the period of the realignment and continue to function at a new level.

Therefore, it is possible say that in the 3 last years under the lead of RCAMAE space education of schoolchildren in Kazakhstan has moved to a new level and this increase bodes well for the future.

The Government of the Republic of Kazakhstan plans to refine the additional education system in space education of schoolchildren. In 2009 children of Kazakhstan, will receive a gift of unique Astrocomplex - a subdivision of National academic and sanitary centre "Bobek". It will be equipped with a telescope with $60 \mathrm{~cm}$ mirror and a Planetarium with a 10-metre diameter of the dome.

Based on the Republican centre of academic methods in additional education, the plans are the following:

(a) To create a Republican Committee dedicated to space education of schoolchildren (which will include scientist, teachers and experts);

(b) To create a state level system of continuous space education of schoolchildren which will base in a newly built regional astro-centres and complexes under the lead of RCAMAE and Astro-complex "Bobek";

(c) To create a Republican program of financing the space education of schoolchildren;

(d) To create a system of selecting and training student for International Astronomy Olympiads and contest;

(e) To create a domestic methodical base (create and publish training software, didactic and methodological materials) for space education;

$(f)$ To equip various types of organizations with modern equipment and materials for space education;

(g) To create an educational portal of space education in our Republic in Internet;

(h) To constantly conduct trainings for teachers to increase their knowledge in space education.

I certainly hope these plans will become true.

\section{References}

Zagainova, V. I. 2003, Astronomy. Practical Course (Almaty: Mektep)

Zagainova, V. I. 2006, Kocymsha bilim zhene terbie. Bneshkoljnik Kazakhstana, 1, 35

Zagainova, V. I. 2007, Kocymsha bilim zhene terbie. Bneshkoljnik Kazakhstana, 2, 63

Zagainova, V. I. 2008, Kocymsha bilim zhene terbie. Bneshkoljnik Kazakhstana, 4, 62

Zagainova, V. I. \& Tokberghenova, U. K. 2000, Entertaining Hands-on classes on astronomy

(Almaty: The Republican Publishing Office of Kazakh Academy of Education) (in Russian)

Zagainova, V. I. et al. 2003, Physics (Almaty: Mektep) (in Russian) 